\title{
Roles of the School Psychologist-Current versus Preferred Roles in the Greek Schools: A Case Study from the Island of Crete
}

\author{
Maria Panteri $^{1, *(\mathbb{D})}$, Juan Calmaestra ${ }^{2}$ and Verónica Marín-Díaz ${ }^{1}$ (D) \\ 1 Department of Education Sciences, University of Córdoba, 14071 Andalusia, Spain; vmarin@uco.es \\ 2 Department of Psychology, University of Córdoba, 14071 Andalusia, Spain; juan.calmaestra@uco.es \\ * Correspondence: mar_krhth@yahoo.gr
}

Citation: Panteri, M.; Calmaestra, J.; Marín-Díaz, V. Roles of the School Psychologist-Current versus

Preferred Roles in the Greek Schools: A Case Study from the Island of Crete. Educ. Sci. 2021, 11, 439. https:// doi.org/10.3390/educsci11080439

Academic Editors: Samuel P. Leon and Inmaculada Garcia Martinez

Received: 22 July 2021

Accepted: 12 August 2021

Published: 18 August 2021

Publisher's Note: MDPI stays neutral with regard to jurisdictional claims in published maps and institutional affiliations.

Copyright: (c) 2021 by the authors. Licensee MDPI, Basel, Switzerland. This article is an open access article distributed under the terms and conditions of the Creative Commons Attribution (CC BY) license (https:// creativecommons.org/licenses/by/ $4.0 /)$.

\begin{abstract}
In the international literature it is frequently reported that school psychologists would like to reduce their involvement in evaluation and assessment activities in favor of an increase in other services and roles. The present study examines the perceptions of teachers and school psychologists regarding the roles of school psychologists on the island of Crete, Greece. For this purpose, an online questionnaire about the current and preferred roles of the school psychologist was distributed. Two hundred and seventy-nine (279) teachers and fifty-seven (57) school psychologists participated in this research study. The analysis and comparison of the participants' responses revealed significant differences in their beliefs about the current and preferred roles of the psychologist. Emphasis was placed by psychologists on systematic interventions such as consultation and by teachers on counseling for their personal problems. Overall, respondents in this study recognized the usefulness of the school psychologist in the educational sector. A unified framework of reference for the range of the schools' psychological services would enhance common understanding and facilitate the professional role of school psychologists and effective student referral to the related professional services.
\end{abstract}

Keywords: school psychologist; perceptions; current roles; preferred roles; psychological services

\section{Introduction}

The need for school psychological services has emerged strongly in recent years. The increased occurrence of learning difficulties and low academic performance [1], children's behavioral problems [2], mental health problems, and new social conditions due to the COVID-19 pandemic [3-5] have led to an understanding of the need to tackle the problems directly and the need to turn to the science of psychology for help. Schools represent the most common entry point for young people to access mental health support, as it has been observed that they are twenty-one times more likely to visit a school-based psychological support service than a community-based mental health care clinic, and students are more likely to ask for help, if available, at school [6]. In this light, school psychological services offer a security framework in which young people learn that seeking help and support, when needed, is normal and accepted, and thus they can receive continuous support, e.g., through academic interventions, mental health services, etc. [7].

In essence, school psychology constitutes the link between the theory and research of education and counseling intervention at school. It seems, from the research literature, that school psychologists are, in general, practitioners whose major professional interests are focused on children, their families, and the school process [8]. The basic education and training of school psychologists (SP) prepares them to be able to provide a range of tasks and services, such as assessments, counseling, crisis management, prevention, mental health program implementation and program evaluation, with special emphasis on the developmental stages of children and young people in schools, families, and other systems [9]. 
Although school psychology as a science and a profession has recently been significantly expanded worldwide [6,10-12], in Greece the profession is still in the process of development, and steps have been taken towards its institutionalization [13]. This rapid development of the field can be observed in the growth in the number of professionals and the organizational and institutional developments, while the importance of professional regulation has been highlighted through certification and accreditation. Nationwide, there is a growing recognition of the need for more school psychologists, which is largely related to mental health, well-being, and crisis management. As it has been shown from previous research [14], the real roles of the psychologist differ significantly from prefecture to prefecture and/or between regions within the country, and the need for research at a local level has also emerged. The research was motivated by the fact that on the island of Crete, one of the largest regions in the country, no previous studies have been conducted on the extent of the dissemination of school psychological services and the perception of the educational community about them. Given the heterogeneity of the island on a geological, economic, and social level, the provision of school psychological services has also followed a discontinuous and heterogeneous course, while psychologists in general schools on the island have only been present for five years. In this context, it is a challenge to explore the views of the school community on the role of SPs and to clearly define their functions; this could help to promote the further institutionalization of school psychological services at a national level and/or influence the promotion of the profession internationally.

\subsection{The Current Roles of the School Psychologist in Greece and Elsewhere}

In the Greek educational system, the roles of school psychologists and the extent to which they fulfill modern educational and social requirements have not been extensively investigated. Nevertheless, a series of studies have confirmed the positive views of stakeholders in the school community regarding the role of school psychologists and the recognition of their multidimensional roles [13].

Regarding the tasks that a psychologist undertakes at school, the National Association of School Psychology in the USA [14] reported that these professionals help students to succeed academically, socially, behaviorally, and emotionally. For that reason, they collaborate with teachers, parents, and other professionals in order to create safe, healthy, and supportive learning environments that strengthen the connections between home, school, and the community for all students.

A school psychologist, through theories and empirical data, plans, manages and/or participates in a system of school psychological services to promote the educational development and mental health of children and young people of school age [15]. Simultaneously, the modern fields of the professional activities of the school psychologist are intended to promote the implementation of children's rights. These include child welfare as the global recognition of the meaning and the value of children's rights has particularly affected school psychology [16].

It has been suggested that there are five key functions within a school psychologist's role, namely, psychological evaluation, intervention, consultation, research, and training, which should be conducted at three levels, namely organizational, group, and individual, across different settings [17]. Similarly, it has been emphasized that school psychologists undertake a range of activities such as assessments, administering counselling to students, teachers and parents, and consultations and interventions in crisis situations [18]. Therefore, the review of the literature on the perceptions of those involved in the educational process, namely teachers, students, parents, and others, reveals the need and desire to move from traditional roles to the more extensive modern roles of school psychologists [10].

In practice, however, research into the real roles undertaken by psychologists in schools revealed that the majority of their time is devoted to special education assessment activities [19], while research data from the USA indicated that school psychologists spend only about $9 \%$ of their time consulting [20]. 
In an international survey on teachers' perceptions of the roles of school psychologists, Greek teachers reported that the most common activities performed by psychologists in their schools were assessments of students with special educational needs, parent counseling, teacher counseling for students' behavioral disorders, and intensive collaboration and consultation with the whole school in order to create a safe, healthy, and supportive learning environment [21]. Similarly, the findings of a longitudinal, international study argued that the main activities of Greek psychologists, based on the time devoted to them, are psychoeducational assessments and student and parent counseling [10].

\subsection{Preferred Roles of the School Psychologists}

In recent years, the literature has shown discrepancies between the perceptions of teachers and psychologists about the role of the latter in the education system. More specifically, teachers seem to attach great value to the traditional role of evaluating students with learning difficulties and, at the same time, highlight the demand for more supportive services from the school psychologists [22]. On the other hand, school psychologists have emphasized a shift from the traditional role of work at an individual level towards a wider role based on dialectical counseling, school-based education, prevention programs, and participation in policymaking [23].

Some researchers have suggested that the following activities and situations could/ should be included in or considered as ideal professional roles for school psychologists: individual counseling with educators, crisis management, parenting work groups, and the prevention of mental health problems [21,24]. In an overview of the desired roles [10,11], it appeared that the (school) psychologists in the participating countries gave priority to the counseling of students, teachers and parents, and prevention. The field of prevention includes prevention programs for major issues, such as school violence, school dropout rates, and employee stress.

In another study, the preferred roles of school psychologists included: (i) the design and implementation of curricula, with a particular emphasis on learning disabilities; (ii) the promotion of students' well-being and mental resilience through prevention and life skills training programs; and (iii) the promotion of school-family cooperation and the implementation of educational programs for parents and teachers, collaboratively or separately [25]. School psychologists involved in Magi and Kikas' research [26] emphasized the importance of counseling in systems, but in practice one can rarely see this in schools.

Considering the fact that, at present, teachers have daily interactions with the students/and they are the professionals who actually refer students when needed to the schools' psychological support services, they are, probably, the most critical members in the students' educational environment [27]. Some studies and clinical reports have revealed that students' disorders and the externalization of problems can increase teachers' anxiety and "confusion", thereby reducing their professional competence [28]. In a qualitative study [29] it was found that school psychologists may have an indirect role in enabling teachers' resilience by mitigating the school-related challenges faced by teachers. The need for counseling support for teachers was also recognized by another study [30], where approximately half of the participants reported that the school psychologists provided them with support/consultation approximately once a week. In general, this type of support includes, for instance, the following activities: (i) general counseling, (ii) teachers' development workshops, (iii) job stress management and (iv) addressing personal issues.

In recent years, and in addition to what was earlier stated in the research studies, state education services and educational policy makers have recognized the need for school psychologists to support a diverse number of students culturally and linguistically. This comes as an emergent need of the rapidly increasing numbers of many diverse linguistic and cultural backgrounds in the public school system, both in the USA and in many European countries, and this trend is expected to continue [31]. A similar picture is presented by the Greek school community, which faces many challenges related to the growing heterogeneity of the student population. This highlights the need for the 
reorientation of the role of the school psychologist from traditional psychoeducational services and its extension to a more systemic way of working [13].

\subsection{The Emerging Role of the School Psychologist in the COVID-19 Era}

The novel coronavirus (COVID-19), which unexpectedly invaded our lives in March of 2020, affected nearly one billion students and learners worldwide [32]. The majority of countries suspended the operation of schools at all levels, leaving around sixty-five per cent $(65 \%)$ of the total student population in home education, switching from traditional school to online teaching.

In the new social reality conditions, with their multidimensional impact (economic, political, environmental, social, cultural, legal, ethical) the role of school psychologists became even more prominent. One year after the outbreak of the pandemic, school psychologists remain unsure of how best to provide psychological services in this context.

The traditional task of the school psychologists to conduct assessments seems impossible using online work platforms. Due to legal difficulties, in most countries it was proposed to suspend all special education assessments until the schools re-opened [33]. Due to the willingness and adaptability of professionals to provide immediate access to services for the completion of this vital task through the use of tele-health platforms, even with the ethical issues raised, the online mode of assessment quickly became a typical mechanism for service delivery [34,35]. However, a better understanding of telepsychology at different developmental ages as well as in the school environment is needed, as the way tele-psychology works in relation to children and adolescents in schools is very relevant [36].

Children were not indifferent to the dramatic impact of the COVID-19 pandemic, as when faced with unexpected and unknown events they typically exhibited various reactions, such as fear, uncertainty, and physical and social isolation and may have missed school for a prolonged period [3]. The literature shows that children during the quarantine period experienced anger, confusion, post-traumatic stress symptoms, family violence, among other things, as a result of the changes in the daily routine [4,37]. Similar reactions to varying degrees of tension were experienced by adults. Additional challenges for children during the COVID-19 pandemic include disruption to academic learning, family financial concerns, greater childhood adverse experiences, grief, and increased time looking at a screen [38].

National surveys in Spain, China and India have highlighted the impact of social isolation on children and adolescents, with researchers from Spain [39] describing that $86 \%$ of participating parents reported changes in their children's emotional state, such as boredom, difficulty concentrating, irritability, and other behaviors. Cases of regression of children's behavior in earlier stages have been reported in Italy [40], while in China increased rates of depressive symptoms have been described [41]. In India, it was found that quarantined children and adolescents experienced feelings of helplessness, fear, an intolerance of the rules, and so on [42].

Holistically understanding the reactions and feelings of all groups of students, teachers, and parents is essential in order to properly address their needs. The priorities of school psychologists should include the disturbances in educational progress, the adaptations of usual coping strategies, and the reduction in adverse psychosocial effects. Emphasis should also be placed on enhancing resilience, i.e., those particular personal attributes that help people to cope with difficult situations, through programs designed to reach the student population, teachers, families, and the wider community affected by crises or/and disasters [43].

Apparently, as a result of the first wave of the COVID-19 pandemic, schools' psychological support services have been rapidly transformed around the world to accommodate the need for prolonged physical distancing [44]. A variety of coping strategies have emerged in an attempt to continue to support children, including providing distance learning, online 
counseling, and various hybrid support configurations, involving both in-person and remote strategies [40].

\subsection{Current Study: A Case Study from the Island of Crete (Greece)}

The purpose of the current study was to evaluate the perceptions of teachers and professional psychologists in relation to: (i) the real/current roles undertaken by school psychologists, (ii) the ideal/desired roles and responsibilities they must assume, and (iii) the usefulness of the work of the psychologist in the school context. The following research questions helped to guide the research:

- What are the perceptions of school psychological services by school psychologists and teachers?

- Do perceptual differences exist between school psychologists and teachers related to the current and preferred roles of psychological services?

- How do teachers and psychologists evaluate the usefulness of school psychological services?

Through the evaluation of the perceptions and beliefs of the stakeholders, an understanding can be obtained about the services they provide or should provide to the educational community, as well as the needs of the profession. The development of a clear identity on the part of the school psychologist and the clarity of their role are key prerequisites for developing professional competence and a sense of confidence and responsibility within the framework of his role [45].

The views of psychologists themselves about their role and professional identity in public education in Greece have not been extensively investigated. The present study can contribute to the exploration of our knowledge in the field of school psychology, with an emphasis on the perspectives of the stakeholders (school psychologists and teachers) and the way they see their role and their professional identity. Studying the aforementioned areas, schools and practitioners may be able to better plan their psychological support services and support programs, as well as be able to give teachers a better understanding of the types of services that school psychologists can offer.

Moreover, the literature highlights the great need for more knowledge about the current and ideal roles of school psychologists, especially in the global context, given that the evolution of the field of school psychology has been uneven across different countries [46,47]. In fact, the professional outline that defines the role of school psychologists but also their specialization does not seem to be common and clear in all countries. In some countries the state license to practice is given after the completion of an undergraduate degree, while in others the completion of a postgraduate program in school psychology is required [11]. The reasons for this uneven development may be related to different national priorities, geographical distances, the legal framework for the use of the SP title, as well as the economic and cultural differences of each country.

\subsubsection{The Greek Context}

The constitutional principle of the Greek state is the provision of free education to all citizens and at all levels, in state schools. The Greek educational system is centralized, and it is governed by legislation and legislative acts (decrees, ministerial decisions).

At the central level, the Ministry of Education and Religions has the administrative responsibility of the education system in all areas, services, and levels, while at the regional level, the regional education directorates supervise the implementation of the national education policy. Locally, the primary and secondary education directorates supervise all schools in their areas of responsibility.

Compulsory education in Greece lasts 11 years and extends from 4 to 15 years. More specifically, the Greek educational system is divided into three levels [48]:

- Primary education which includes kindergartens and primary schools. Preschool education in Greece is compulsory for children from four years of age. Primary 
schools have a six-year compulsory attendance policy and educate children from 6 to 12 years old;

- Secondary education, which includes two levels of study. Middle schools have compulsory attendance and cover the ages 12-15. The second level of secondary education is non-compulsory and includes General High Schools and Vocational High Schools; - Higher education is the last level of the formal education system.

The Greek educational system is characterized by educational inequalities, related to the geographical distribution of school reception and the socio-economic conditions of each region. A view of the Greek education system, according to the Hellenic Statistical Authority [49], shows that since the 1990s an influx of migrants has occurred in the country and $11 \%$ of the student population are immigrants, a fact that has shaped a new reality, namely the multiculturalism of the student population.

Another perspective regarding the Greek educational system relates to the strong differentiation of the educational indicators by prefecture throughout the Greek regions. For example, this is reflected in school dropout rates, where rural areas or tourism-related areas typically have a higher dropout rate within most prefectures than in semi-urban or urban areas [50]. Similar inequalities can be observed in the staffing of schools with psychologists, where some areas, usually urban areas, are adequately provided with school psychological services, while others are not.

Crete is the largest and most populous island in Greece, with a population of over 620,000 . Its economy is mainly based on tourism and agriculture. Regarding the student dropout rate, according to the data of the institute of educational policy, Crete has a high percentage rate compared to the rest of Greece. More specifically, the prefecture of Rethymno presents higher percentages (6.83\% in the Gymnasium and 4.91\% in the Lyceum) compared to the other three prefectures, followed by the prefecture of Lassithi $(4.7 \%$ in the Gymnasium and $1.72 \%$ in the Lyceum) [50].

Ministerial Decision 142628/DG4/2017 sought to provide support for less-favored areas to ensure that psychologists and social workers could undertake their duties in specific schools of general and vocational education if there was a need to support vulnerable social groups or if it was necessary to implement programs for the psychosocial and emotional support of students.

\subsubsection{The Institution of the School Psychologist in Greece}

The school psychology sector in Greece did not follow the same pace of evolution as in other European countries and the USA. It is noteworthy that until the late 1980s, psychology was considered a field of philosophy. The history of school psychology in Greece can be divided into two general periods: the hybrid years, which ended in the 20th century and the thoroughbred years, which gradually started in the new millennium. The first period was characterized as heterogeneous, as experts from the field of pedagogy and psychology coexisted, while the role of the school psychologist was occupied by practitioners from various disciplines. The second period, which extends to the present day, is characterized as genuine. A key element of this period is the expansion of the role of the school psychologist through the provision of counseling and other services [13].

The last few decades of the evolutionary course of school psychology in Greece have been influenced by various events [10]. In the late 1980s and early 1990s, independent departments of psychology were established at the University of Crete, the University of Athens, the University of Thessaloniki, and Panteion University, where degrees in psychology as well as postgraduate programs in school psychology were offered [51].

In Greece, the institutionalization of the services of school psychologists is in progress, especially in recent years. The first psychologists to work in the Greek public educational system were appointed in special education schools in 1989 and these positions did not require any specialization in school psychology. After that, the formal training of school psychologists in Greek universities followed. Subsequently, Law 2817/2000 established the provision of psychological services in schools and the establishment of state assessment 
centers, i.e., Centers for Differential Diagnosis, Assessment and Support (CDDAS) to provide services by members of interdisciplinary teams, including psychologists [50]. In 2008, with Law 3699/2008, special education was integrated into the Ministry of Education, where the emphasis on assessment continued, maintaining a medical model of services.

Recently, the institutions of the School Education Support Network (S.D.E.Y.) and the Interdisciplinary Committees for Educational Evaluation and Support (E.D.E.A.Y.) (Government Gazette 315/2014) were introduced, in the framework of which psychologists were employed in general education schools. Usually, a psychologist in collaboration with a social worker is hired at an S.D.E.Y. and offers their services in five different general education schools. The role of the school psychologist is advisory, supportive, and therapeutic to students, their families, and the educational staff and includes assessment, individual and group counseling, consultation for teachers, the implementation of inclusive education programs, and the promotion of prevention, information and awareness programs for teachers, parents, and students.

Regarding the qualifications of school psychologists in Greece and their work in schools, specialization is not necessarily required, as is the case in USA and in other countries in Western Europe [11]. Thus, psychologists, regardless of their specialization, have the opportunity to work within schools. However, in recent years there has been a change in the institutional framework, following the decision of the Legal Council of the State in 2011, which ruled that those psychologists specializing in school psychology should be hired as a priority in education. Additionally, the Institute of Educational Policy (IEP) in 2017 established criteria (342/19-01-2017) according to which the candidate psychologists are evaluated based on whether they fulfill the conditions in order to be included in the list of school psychologists. Among the necessary criteria are a postgraduate education in school psychology and an internship in special and general education schools.

\section{Materials and Methods}

The present study examined the perceptions of teachers and school psychologists about the roles of school psychologist in the region of the island of Crete, Greece. For this purpose, an exploratory study was carried out using a descriptive design.

\subsection{Participants}

The participant sample in this study consisted of a total of two hundred and seventynine (279) teachers and fifty-seven (57) school psychologists working in the four prefectures of the region of Crete during the school year 2018-2019. The sample was selected by the process called "snowball sampling", as the researchers first sent the questionnaire to schools in Crete, which they were already familiar with and then the questionnaire was forwarded to other colleagues. The majority of participants in both groups were female, as indicated by Table 1.

Table 1. Gender Distribution.

\begin{tabular}{ccc}
\hline Gender & Teachers [f (\%)] & Psychologists [f (\%)] \\
\hline Male & $90(32.3 \%)$ & $7(12.3 \%)$ \\
Female & $189(67.7 \%)$ & $50(87.7 \%)$ \\
Total & $279(100 \%)$ & $57(100 \%)$ \\
\hline
\end{tabular}

Most participating teachers were in the age group of $36-45(\mathrm{M}=41.77 ; \mathrm{SD}=8.3)$, while the psychologists were younger $(\mathrm{M}=35.28 ; \mathrm{SD}=5.1)$, as shown in Table 2 . 
Table 2. Age Distribution.

\begin{tabular}{ccc}
\hline Age & Teachers [f (\%)] & Psychologists [f (\%)] \\
\hline $25-35$ & $67(24 \%)$ & $36(63.2 \%)$ \\
$36-45$ & $129(46.2 \%)$ & $18(31.6 \%)$ \\
$46-55$ & $69(24.7 \%)$ & $3(5.3 \%)$ \\
$\geq 56$ & $14(5 \%)$ & $0(0 \%)$ \\
Total & $279(100 \%)$ & $57(100 \%)$ \\
\hline
\end{tabular}

The distribution of the sample regarding its prefecture of Crete is shown in Table 3. Most of the teachers and psychologists worked in the two largest prefectures of the island, namely Heraklion and Chania, which may be related to recruitment rates per region.

Table 3. Prefecture Distribution.

\begin{tabular}{ccc}
\hline Prefecture & Teachers [f (\%)] & Psychologists [f (\%)] \\
\hline Heraklion & $138(49.5 \%)$ & $26(45.6 \%)$ \\
Chania & $74(26.5 \%)$ & $15(26.3 \%)$ \\
Rethymno & $47(16.8 \%)$ & $12(21 \%)$ \\
Lasithi & $20(7.2 \%)$ & $4(7.1 \%)$ \\
Total & $279(100 \%)$ & $57(100 \%)$ \\
\hline
\end{tabular}

Most of the teachers (39.8\%) and psychologists (56.1\%) worked in primary schools, while a large percentage of teachers ( $35 \%$ ) also worked in high schools (Table 4 ).

Table 4. School Distribution.

\begin{tabular}{ccc}
\hline Type of School & Teachers [f (\%)] & Psychologists [f (\%)] \\
\hline Kindergarten & $25(9 \%)$ & $0(0 \%)$ \\
Elementary & $111(39.8 \%)$ & $32(56.1 \%)$ \\
Secondary & $45(16.1 \%)$ & $4(7 \%)$ \\
High school & $98(35 \%)$ & $5(8.8 \%)$ \\
Vocational school & $70(25.1 \%)$ & $16(28.1 \%)$ \\
Total & $279(100 \%)$ & $57(100 \%)$ \\
\hline
\end{tabular}

\subsection{Instrument}

The current study aimed to investigate the role(s) of school psychologists as perceived by teachers and compared the teachers' perceptions with the roles identified by the practitioners (school psychologists) themselves. A quantitative research technique was implemented and a questionnaire was used as the data-gathering instrument. Each participant completed an online, anonymous questionnaire on the "Google Forms" platform, adapted from a previous national document [26]. In this way, it could be sent electronically to geographical locations without the presence of the researcher, which eliminates the potential influence of the researcher. The questionnaire was translated into the Greek language by two native Greek speakers and was administered to a random sample of five teachers to test the comprehension and rewording of the items. Quantitative data were analyzed with SPSS Statistics (IBM, version 22).

A description of the instrument is presented below:

- Part I: Demographic information, including gender, age, type, and place of school;

- Part II: (a) Twenty-one (21) items about the preferred roles of school psychologists, and (b) twenty-one (21) items regarding the current roles and tasks. Questions were answered on a 3-point scale ( 1 = disagree, 2 = somewhat agree, 3 = agree);

- Part III: Two statements for the evaluation of the satisfaction regarding the cooperation between the teacher and the psychologist. 
The reliability of the ratings in the questionnaire was determined using Cronbach's alpha coefficient. The reliability of the 21 items related to the ideal roles was 0.86 and for the 21 items related to the current roles the reliability was 0.84 .

\subsection{Procedure}

The authors initially directed the questions to school administrators via telephone and then through e-mail. Although the traditional mailing mode has been found to result in greater response rates than web-based administration research tools [52], in this study, due to a lack of time, the online questionnaire was sent to the administrators of each school. A follow-up reminder e-mail was sent to all those school districts whose administrative authorities and/or Principals did not respond to the initial e-mail within three weeks. In the case of a school's agreement to participate in this study, administrators were sent information through letters explaining the aims of this study; they also received an informed consent form. The survey was conducted from January 2019 to April 2019. Participation was voluntary and the participants had the opportunity to withdraw from the study at any phase.

\subsection{Measures}

A frequency analysis was used to describe the sample responses regarding the usefulness of the school psychologist. In order to analyze, in a comparative way, the frequencies between the two variables, contingency tables were used while the level of minimum significance adopted was $p=0.05$. In order to check whether the sample had different perceptions about the actual and preferred roles of psychologists the Paired Sample $t$-test was applied.

An exploratory factor analysis was carried out, which allowed us to compare and contrast the underlying structure of the instrument with the theoretical structure considered in its original version, providing important clues to study the construct validity and improve the questionnaire based on the results obtained. Prior to the application of the EFA, it was necessary to check some criteria about its viability: the KMO sample adequacy measure and the Bartlett sphericity test were used. Regarding the determinant of the correlation matrix, its value was 0.000 , which indicated that there were statistically significant correlations between the variables which were not homogeneous and, therefore, the data were suitable for the realization of the EFA. The sample adequacy measure also yielded a statistical value of $\mathrm{KMO}=0.861$, which is considered meritorious.

\section{Results}

\subsection{Model Testing Results}

A Principal Component Analysis and the varimax rotation method with Kaiser normalization were applied to the 21 items related to the preferred roles for the school psychologists in order to reduce the number of variables in our data to a smaller set. The conceptual correlation of the variables led to the creation of four grouped factors. Detailed information is presented in Table 5.

\subsection{Comparison between the Ideal and the Actual Roles of the School Psychologist within Groups}

Teachers Group: According to the results, statistically significant differences were observed in most of the responses from the teachers' group regarding what they considered ideal school psychologists should do and the activities they observed school psychologists to actually perform. In particular, while teachers wished that school psychologists' work roles at school included regular consultation through lectures and conversations $(t=5.145$; $\mathrm{df}=278 ; p=0.000)$, as well as teaching sessions in order to gain a better understanding of students' problems $(t=3.909 ; \mathrm{df}=278 ; p=0.000)$, they did not see this happening. 
Table 5. Rotated Component Matrix ${ }^{a}(n=336)$.

\begin{tabular}{|c|c|c|c|c|c|}
\hline & \multirow{2}{*}{ Item } & \multicolumn{4}{|c|}{ Factors } \\
\hline & & 1 & 2 & 3 & 4 \\
\hline \multirow{7}{*}{$\begin{array}{l}\text { Child-Centered } \\
\text { Activities } \\
\alpha=0.859\end{array}$} & $\begin{array}{l}\text { 9. School psychologists should assess children for special } \\
\text { educational provision }\end{array}$ & 0.565 & & & \\
\hline & $\begin{array}{l}\text { 6. School psychologists should carry out preventive group } \\
\text { work with children }\end{array}$ & 0.624 & & & \\
\hline & $\begin{array}{l}\text { 1. School psychologists should counsel students with } \\
\text { learning difficulties and behavioral problems }\end{array}$ & 0.639 & & & \\
\hline & $\begin{array}{l}\text { 17. School psychologists should run group therapy for } \\
\text { children who have similar problems }\end{array}$ & 0.738 & & & \\
\hline & $\begin{array}{l}\text { 19. School psychologists should consult with parents whose } \\
\text { children have learning difficulties and behavioral problems }\end{array}$ & 0.751 & & & \\
\hline & $\begin{array}{l}\text { 5. School psychologists should counsel students with } \\
\text { personal and family problems }\end{array}$ & 0.782 & & & \\
\hline & $\begin{array}{l}\text { 11. School psychologists should counsel students with } \\
\text { emotional problems }\end{array}$ & 0.833 & & & \\
\hline \multirow{6}{*}{$\begin{array}{l}\text { Activities } \\
\alpha=0.770\end{array}$} & $\begin{array}{l}\text { 15. School psychologists should assess pupils to compose } \\
\text { effective study programs }\end{array}$ & & 0.472 & & \\
\hline & 20. School psychologists should offer career guidance & & 0.566 & & \\
\hline & $\begin{array}{l}\text { 10. School psychologists should teach classes to gain a better } \\
\text { understanding about problematic pupils in the classroom }\end{array}$ & & 0.662 & & \\
\hline & $\begin{array}{l}\text { 2. School psychologists should regularly consult with the } \\
\text { school administration team and teachers through lectures } \\
\text { and conversations }\end{array}$ & & 0.681 & & \\
\hline & $\begin{array}{l}\text { 3. School psychologists should give quick and } \\
\text { concrete advice }\end{array}$ & & 0.740 & & \\
\hline & $\begin{array}{l}\text { 4. School psychologists should act as mediators in problems } \\
\text { between teachers and pupils }\end{array}$ & & 0.744 & & \\
\hline \multirow{8}{*}{$\begin{array}{l}\text { System Counseling } \\
\qquad \alpha=0.745\end{array}$} & 13. School psychologists should counsel school & & & & \\
\hline & $\begin{array}{l}\text { administrators and teachers on how to improve planning, } \\
\text { learning, and working conditions }\end{array}$ & & & 0.571 & \\
\hline & 21. School psychologists should advise school & & & & \\
\hline & $\begin{array}{c}\text { administrators and teachers on how to improve } \\
\text { working conditions }\end{array}$ & & & 0.622 & \\
\hline & 18 School nsycholooists should counsel teachers on their & & & & \\
\hline & $\begin{array}{l}\text { 18. School psychologists should counsel teachers on their } \\
\text { personal problems }\end{array}$ & & & 0.677 & \\
\hline & $\begin{array}{l}\text { 7. School psychologists should act as mediators in problems } \\
\text { between school and parents }\end{array}$ & & & 0.687 & \\
\hline & $\begin{array}{l}\text { 8. School psychologists should act as mediators in problems } \\
\text { between the school administration team and teachers }\end{array}$ & & & 0.739 & \\
\hline \multirow{5}{*}{$\begin{array}{l}\text { Management } \\
\text { Students' Problem } \\
\quad \alpha=0.788\end{array}$} & $\begin{array}{l}\text { 14. School psychologists should be able to eliminate pupils' } \\
\text { learning difficulties and behavioral problems }\end{array}$ & & & & 0.596 \\
\hline & 12. School psychologists should consult with teachers on & & & & \\
\hline & how to manage pupils who have learning difficulties and & & & & 0.713 \\
\hline & behavioral problems (or other special needs) & & & & \\
\hline & $\begin{array}{c}\text { 16. School psychologists should carry out training for } \\
\text { teachers to help them manage different situations in the } \\
\text { classroom better }\end{array}$ & & & & 0.744 \\
\hline
\end{tabular}

${ }^{\text {a }}$ Rotation converged in 6 iterations.

Another point that emerged was that while teachers viewed the psychologists' mediating role as ideal in various critical situations, they responded that this activity was not performed by the school psychologists in their daily work practice. In detail, the responses that represented the ideal mediating role of school psychologists in the problems between teachers and students $(\mathrm{M}=2.37 ; \mathrm{SD}=0.84)$ and those that showed the real role according to their views $(\mathrm{M}=1.88 ; \mathrm{SD}=0.86)$ differed significantly $(\mathrm{t}=9.876 ; \mathrm{df}=278 ; p=0.000)$. 
Additionally, the statistical analysis showed that teachers wished that school psychologists would give quick and concrete advice $(\mathrm{M}=2.84 ; \mathrm{SD}=0.38)$, while they perceived that they did not really do this $(\mathrm{M}=2.59 ; \mathrm{SD}=0.52)(\mathrm{t}=8.614 ; \mathrm{df}=278 ; p=0.000)$. Moreover, the teachers considered it ideal to receive support from school psychologists regarding their own personal problems $(\mathrm{M}=2.44 ; \mathrm{SD}=0.80)$ but they did not actually receive this support, according to their responses $(\mathrm{M}=1.68 ; \mathrm{SD}=0.79)(\mathrm{t}=13.052 ; \mathrm{df}=278 ; p=0.000)$.

School Psychologists (SPs): Although SPs recognized the need to provide consultation to educational staff, it was not within the scope of the activities that they actually performed. More specifically, they assigned lower scores to the real roles $(\mathrm{M}=2.88 ; \mathrm{SD}=0.47)$ and higher scores to the ideal ones $(\mathrm{M}=2.95 ; \mathrm{SD}=0.22)$, in particular concerning collaborative consultation with teachers on how to manage students who have learning difficulties and behavioral problems or other special needs $(t=2.056$; $\mathrm{df}=56, p=0.044)$. A difference in the statement concerning the provision of career guidance was also observed. The SPs assigned a higher score to the ideal $(\mathrm{M}=2.72 ; \mathrm{SD}=0.56)$ roles than the real roles $(\mathrm{M}=2.28$; $\mathrm{SD}=0.82$ ), meaning that while they scored career guidance as a preferred task, they did not in fact provide it to the students $(\mathrm{t}=3.916 ; \mathrm{df}=56 ; p=0.000)$.

It is worth noting that the group of teachers seemed to have higher and perhaps more demanding expectations than those shown by the group of school psychologists. The latter, apparently, did not correspond to reality, while psychologists themselves estimated that they did perform the tasks expected of them.

\subsection{The Usefulness of the School Psychological Support Services}

The majority of the teachers $(n=205 ; 73.5 \%$; $\mathrm{SD}=0.49)$ and psychologists $(\mathrm{n}=54$; $94.7 \%$ ) in the sample assessed the provision of the school psychological support services as very helpful, while $24.7 \%(\mathrm{n}=69)$ of the teachers thought that this work was helpful. Only three psychologists $(5.3 \%$; $S D=0.22)$ considered their work to be useful in the school context. Therefore, the higher frequency of reports by both teachers and school psychologists themselves confirms the importance and usefulness of school psychologists throughout the school community and this can also be seen in Figure 1.

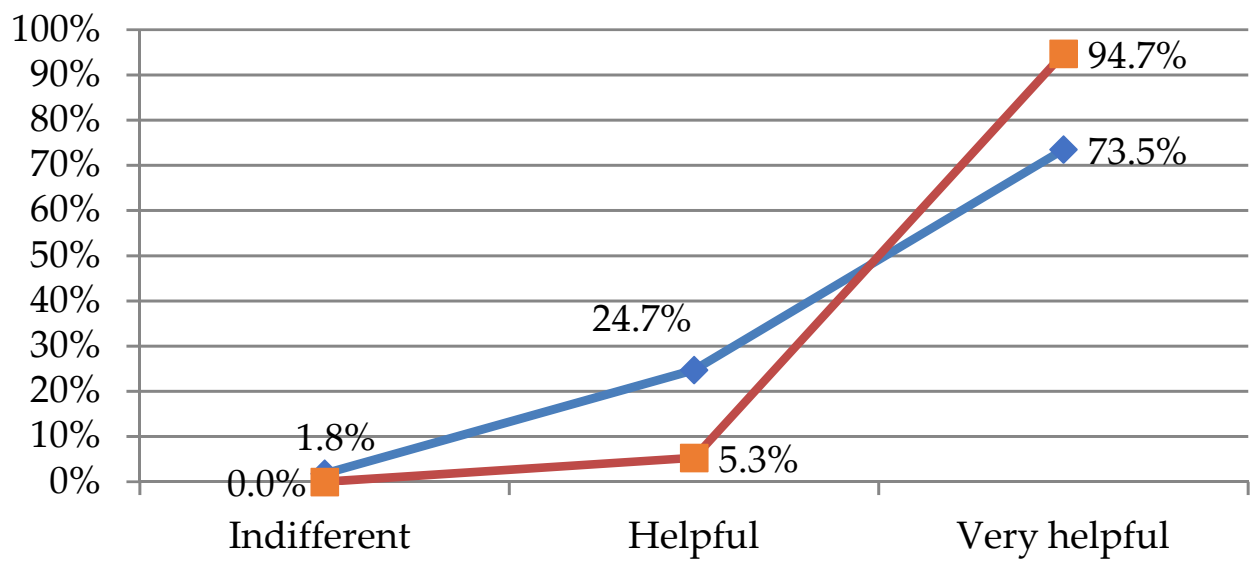

$\sim$ Teachers $\quad-$ Psychologists

Figure 1. Frequencies about usefulness of the work of the School Psychologist.

However, as indicated in Table 6, there was a statistically significant difference between the responses of the sample participants, with school psychologists rating the utility of their work more highly $\left[\chi^{2}(2,336)=12.168 ; p=0.002\right]$. 
Table 6. Chi-Square Tests for question "On the average, how helpful do you think school psychologist's work is for the school?".

\begin{tabular}{cccc}
\hline & Value & df & Asymp. Sig. (2-Sided) \\
\hline Pearson Chi-Square & $12.168^{\mathrm{a}}$ & 2 & 0.002 \\
Likelihood Ratio & 15.841 & 2 & 0.000 \\
Linear-by-Linear Association & 11.704 & 1 & 0.001 \\
N of Valid Cases & 336 & & \\
\hline a 2 cells $\left(33.3^{\circ}\right)$ have expected count less than 5 . The minimum expected count is 0.85.
\end{tabular}

a 2 cells $(33.3 \%)$ have expected count less than 5 . The minimum expected count is 0.85 .

\section{Discussion}

The roles and functions of school psychologists have been subject to continued debate, with discussions often focusing on how the profession can expand from its emphasis on assessment-related activities [24] to greater involvement in roles such as designing and implementing academic and behavioral interventions, consultation with teachers and administrators [26,53], administering group and individual counseling to students [6], distance counseling [34] and other wellbeing and school development-related activities.

The practice of school psychologists encompasses direct (supporting children and youth, assessment, and program planning) and indirect interventions (school development, supervision, and consultation with teachers, parents, and other professionals) [10]. Consequently, school psychologists nowadays can deliver a wide range of services designed to improve the outcomes of students and their families [54]. These include tasks such as the conduction of various assessments, consulting on a range of issues, working with parents, in-service training, counseling, programmed evaluations, research and development, and responding to critical incidents.

Student assessment, as one of the most common tasks of school psychologists, should be reviewed in the new online learning environments on the rise, as validity issues are raised and the need for further research on the use and interpretation of online assessment methods is emphasized [55].

The results of this study show that there are significant differences in teachers' and psychologists' perceptions regarding the role of the latter at schools. In particular, there seems to be different expectations regarding the desirable/ideal and current/actual roles that school psychologists assume and are called upon to perform.

Research indicates that many school psychologists wish to expand their role from traditional client-centered tasks to more systemic interventions such as consultation [22]. The psychologists who participated in this study declared that they spent most of their time on student counseling, dealing with learning, behavioral, and social difficulties. This finding is in line with previous studies, which revealed a tendency to continue using the client-centered model [6].

In addition, the school psychologists in the sample of this study felt that part of their daily activities was prevention. This was a rather unexpected outcome, since previous research studies showed that most school psychologists reported feeling less competent in providing prevention activities than assessment and counseling activities [56]. In another study, almost half of the participating psychologists reported that their training prepared them somewhat poorly or did not prepare them at all for providing prevention activities or intervention in crisis situations [2].

Although in the school psychology literature there is a lot of discussion about work at the system level, in Greece this is seldom seen in practice, according to both schoolteachers and school psychologists. Furthermore, the results of this study indicate that the teaching staff in Greek schools wished that school psychologists would play a mediating role in problems arising with other staff, as well as wishing that they were able to provide counseling support on their personal problems; practically however, they did not see this happening. This finding, in a way, seems to be confirmed by the literature where it is mentioned that the provision of socio-emotional support to fellow teachers is a degraded task of the psychologist $[29,56]$. However, in a study of the role of the school psychologist 
in the COVID-19 era [44], the role of teachers' support on their own personal problems seemed to emerge significantly.

The results are, in general, in line with the literature, which indicates that not much time is left for consultation, as a wide variety of child-centered activities predominate [24,26] and predetermine the roles and responsibilities of SPs at school. Greek school psychologists also declared that career guidance and counseling was not among the tasks they undertook, even though it was among their desired list of professional tasks/roles at school.

However, an interesting outcome of the present study which is different to previous research findings is the following: providing psychological services to parents as an SP's task was not included as part of the actual role of school psychologists, while the research literature demonstrates the importance of it. A large aspect of the SPs' practice involves providing direct services to learners; however, school psychologists are also trained to facilitate teacher and parent development, and to intervene at the level of the school as an organization, including parents [57].

It can safely be concluded that while those professionals involved in the educational process wish to continue providing individual counseling to students to an even greater extent, they also appraise the psychological support to the parents to be highly important $[4,6,26]$. Overall, the current results, as well as previous studies, suggest that the field of school psychology is expanding to utilize its integrated education beyond engaging with assessment, in a wide range of tasks and activities [8,56,58].

Aside from the above findings, the results of the current study are consistent with those of previous research on the positive view and recognition of the importance of the role of the school psychologist in Greece [13,58]. Teachers seem to support the institution of the school psychologist, as they consider it helpful or very helpful, thus highlighting its necessity in the school context.

\section{Conclusions}

Overall, the findings from the current study concur with those from previous research, in that school-based psychological support services are perceived as being helpful and valuable services [58]. In general, the expectations about these services and the professionals who offer them, namely school psychologists, are somewhat similar to the expectations found in related research studies in other countries. The latter include the desire for more work with students and also with teachers, whereas work at the system level is considered equally important.

At the time (January-April 2019) of the survey for the needs of this study, COVID-19 was not a threat, and thus, the findings reflect the situation and perception of the preCoronavirus era. However, the role and duties of the school psychologists have changed dramatically and quickly since the beginning of the COVID-19 pandemic. Notably, a sudden health and educational crisis $[32,59]$ required increased crisis management knowledge and skills and responsibilities to tackle the problematic situations that arose efficiently. Parents, students, teachers, and other groups needed to be communicated with regarding the new schooling requirements and school psychological support needs in due time, allowing them to flexibly adapt to them. Recent research studies [60] referred to the new schooling situation worldwide and examined it from a multidimensional perspective.

As the impact of the COVID-19 pandemic remains in our lives, school psychology has to adapt across all aspects of training and practice. Indeed, assessment, intervention, consultation, and other forms of school psychological services have begun to be adapted and will likely look significantly different in the foreseeable future [41].

Notwithstanding, this study's outcomes can be taken into account by the Greek Ministry of Education for the long-term design of a system of school psychological services in the Greek educational system, through a holistic consideration of school needs at a system level. In a similar vein, we could say that the perceptions of the stakeholders themselves, namely teachers, administrators, school psychologists, and students, can reinforce the institutionalization of psychological services within school units, under specific conditions, 
as they know and can empirically convey the needs of their schools to policymakers. Therefore, there is a need for continuous advocacy, on the part of school psychologists, as well as their professional associations, their role, and professional identity within the school context, in order to be able to respond in a timely and appropriate manner to the constantly changing socio-psychological conditions.

Author Contributions: Conceptualization, M.P.; methodology, J.C. and V.M.-D.; validation M.P., J.C. and V.M.-D.; formal analysis, M.P. and J.C.; investigation, M.P. and J.C.; resources, M.P. and J.C.; data curation, M.P. and J.C.; writing—original draft preparation, M.P., J.C. and V.M.-D.; writing—review and editing, V.M.-D.; visualization, V.M.-D.; supervision, V.M.-D. All authors have read and agreed to the published version of the manuscript.

Funding: This research received no external funding.

Institutional Review Board Statement: Not applicable.

Informed Consent Statement: Informed consent was obtained from all subjects involved in the study.

Data Availability Statement: The data that support the findings of this study are available from the corresponding author upon reasonable request.

Conflicts of Interest: The authors declare no conflict of interest.

\section{References}

1. Rodericks, R.; Vu, U.; Holmes, J.H.; Ryan, J.; Sentell, T. Insights in Public Health. Data Highlights from the Hawaii Youth Risk Behavior Survey: Links between Academic Achievement and Health Behaviors. Hawaii J. Med. Public Health 2018, 77, 297-304. Available online: https:/ / www.ncbi.nlm.nih.gov/pmc/articles/PMC6218687/ (accessed on 1 November 2018).

2. Hanchon, T.A.; Fernald, L.N. The provision of counselling services among school psychologists: An exploration of training, current practices, and perceptions. Psychol. Sch. 2013, 50, 651-671. [CrossRef]

3. Jiao, W.Y.; Wang, L.N.; Liu, J.; Fang, S.F.; Jiao, F.Y.; Pettoello-Mantovani, M.; Somekh, E. Behavioral and Emotional Disorders in Children during the COVID-19 Epidemic. J. Pediatr. 2020, 221, 264-266.e1. [CrossRef]

4. Humphreys, K.L.; Myint, M.T.; Zeanah, C.H. Increased Risk for Family Violence during the COVID-19 Pandemic. Pediatrics 2020, 146, 1-5. [CrossRef]

5. Merikangas, K.R.; He, J.-P.; Burstein, M.; Swendsen, J.; Avenevoli, S.; Case, B.; Georgiades, K.; Heaton, L.; Swanson, S.; Olfson, M. Service Utilization for Lifetime Mental Disorders in U.S. Adolescents: Results of the National Comorbidity Survey-Adolescent Supplement (NCS-A). J. Am. Acad. Child Adolesc. Psychiatry 2011, 50, 32-45. [CrossRef]

6. Eklund, K.; Meyer, L.; Way, S.; McLean, D. School psychologists as mental health providers: The impact of staffing ratios and Medicaid on service provisions. Psychol. Sch. 2017, 54, 279-293. [CrossRef]

7. Eklund, K.; von der Embse, N.; Minke, K. School psychologists and school-based Medicaid reimbursement. Regist. Rep. 2015, 41, 40-43.

8. Fallon, K.; Woods, K.; Rooney, S. A discussion of the developing role of educational psychologists within Children's Services. Educ. Psychol. Pr. 2010, 26, 1-23. [CrossRef]

9. Lee, K.; Woods, K. Exploration of the developing role of the educational psychologist within the context of "traded" psychological services. Educ. Psychol. Pract. 2017, 33, 111-125. [CrossRef]

10. Jimerson, S.R.; Annan, J.; Skokut, M.; Renshaw, T.L. Educational Psychology in New Zealand. Sch. Psychol. Int. 2009, 30, 443-455. [CrossRef]

11. Jimerson, S.R.; Skokut, M.; Cardenas, S.; Malone, H.; Stewart, K. Where in the World is School Psychology? Sch. Psychol. Int. 2008, 29, 131-144. [CrossRef]

12. Oakland, T.; Hatzichristou, C. Professional Preparation in School Psychology: A Summary of Information from Programs in Seven Countries. Int. J. Sch. Educ. Psychol. 2014, 2, 223-230. [CrossRef]

13. Hatzichristou, C. School Psychology; Typothito: Athens, Greece, 2011.

14. National Association of School Psychologist. Model for comprehensive and integrated school psychological services. Sch. Psychol. Rev. 2010, 39, 320-333. [CrossRef]

15. D'Amato, R.C.; Zafiris, C.; McConnell, E.; Dean, R.S. The History of School Psychology: Understanding the Past to Not Repeat It; Oxford University Press (OUP): Oxford, UK, 2011; pp. 1-71.

16. Kosher, H.; Jiang, X.; Ben-Arieh, A.; Huebner, E.S. Advances in children's rights and children's well-being measurement: Implications for school psychologists. Sch. Psychol. Q. 2014, 29, 7-20. [CrossRef] [PubMed]

17. Rumble, A.; Thomas, G. Reflections on the Role of the Educational Psychologist within a Multi-Academy Trust. Educ. Psychol. Res. Pract. 2017, 3, 15-28. [CrossRef]

18. Perfect, M.M.; Morris, R.J. Delivering school-based mental health services by school psychologists: Education, training, and ethical issues. Psychol. Sch. 2011, 48, 1049-1063. [CrossRef] 
19. Villarreal, V. Mental Health Collaboration: A Survey of Practicing School Psychologists. J. Appl. Sch. Psychol. 2017, $34,1-17$. [CrossRef]

20. Castillo, J.M.; Curtis, M.J.; Gelley, C. School psychology 2010-Part 2: School psychologists' professional practices and implications for the field. Communique 2012, 40,4-6.

21. Farrell, P.; Jimerson, S.R.; Kalambouka, A.; Benoit, J. Teachers' Perceptions of School Psychologists in Different Countries. Sch. Psychol. Int. 2005, 26, 525-544. [CrossRef]

22. Thielking, M.; Jimerson, S.R. Perspectives Regarding the Role of School Psychologists: Perceptions of Teachers, Principals, and School Psychologists in Victoria, Australia. Aust. J. Guid. Couns. 2006, 16, 211-223. [CrossRef]

23. Gilman, R.; Medway, F.J. Teachers' perceptions of school psychology: A comparison of regular and special education teacher ratings. Sch. Psychol. Q. 2007, 22, 145-161. [CrossRef]

24. Watkins, M.W.; Crosby, E.G.; Pearson, J.L. Role of the School Psychologist. Sch. Psychol. Int. 2001, 22, 64-73. [CrossRef]

25. Squires, G.; Farrell, P.; Woods, K.; Lewis, S.; Rooney, S.; O'Connor, M. Educational Psychologists' Contribution to the Every Child Matters Agenda: The parents' view. Educ. Psychol. Pr. 2007, 23, 343-361. [CrossRef]

26. Mägi, K.; Kikas, E. School Psychologists' Role in School. Sch. Psychol. Int. 2009, 30, 331-346. [CrossRef]

27. Bell, H.D.; McKenzie, V. Perceptions and Realities: The Role of School Psychologists in Melbourne, Australia. Aust. Educ. Dev. Psychol. 2013, 30, 54-73. [CrossRef]

28. Fleming, J.L.; Mackrain, M.; Lebuffe, P.A. Caring for the Caregiver: Promoting the Resilience of Teachers. In Handbook of Resilience in Children; Springer: New York, NY, USA, 2013; pp. 387-397.

29. Beltman, S.; Mansfield, C.F.; Harris, A. Quietly sharing the load? The role of school psychologists in enabling teacher resilience. Sch. Psychol. Int. 2015, 37, 172-188. [CrossRef]

30. Wang, C.; Ni, H.; Ding, Y.; Yi, C. Chinese teachers' perceptions of the roles and functions of school psychological service providers in Beijing. Sch. Psychol. Int. 2015, 36, 77-93. [CrossRef]

31. Vega, D.; Lasser, J.; Afifi, A.F.M. School Psychologists and the Assessment of Culturally and Linguistically Diverse Students. Contemp. Sch. Psychol. 2016, 20, 218-229. [CrossRef]

32. UNESCO and Partners Launch of the Geneva Global Education in Emergencies Hub. Available online: https://en.unesco.org/ news/ unesco-and-partners-launch-geneva-global-education-emergencies-hub (accessed on 20 February 2021).

33. Farmer, R.L.; McGill, R.J.; Dombrowski, S.C.; Benson, N.F.; Smith-Kellen, S.; Lockwood, A.B.; Powell, S.; Pynn, C.; Stinnett, T.A. Conducting Psychoeducational Assessments During the COVID-19 Crisis: The Danger of Good Intentions. Contemp. Sch. Psychol. 2021, 25, 27-32. [CrossRef]

34. Callahan, J.L. Introduction to the special issue on telepsychotherapy in the age of COVID-19. J. Psychother. Integr. 2020, 30, 155-159. [CrossRef]

35. Fischer, A.J.; Schultz, B.K.; Collier-Meek, M.A.; Zoder-Martell, K.A.; Erchul, W.P. A critical review of videoconferencing software to support school consultation. Int. J. Sch. Educ. Psychol. 2016, 6, 12-22. [CrossRef]

36. Mccord, C.; Bernhard, P.; Walsh, M.; Rosner, C.; Console, K. A consolidated model for telepsychology practice. J. Clin. Psychol. 2020, 76, 1060-1082. [CrossRef] [PubMed]

37. Vu, N.L.; Jouriles, E.N.; McDonald, R.; Rosenfield, D. Children's exposure to intimate partner violence: A meta-analysis of longitudinal associations with child adjustment problems. Clin. Psychol. Rev. 2016, 46, 25-33. [CrossRef] [PubMed]

38. Golberstein, E.; Wen, H.; Miller, B.F. Coronavirus Disease 2019 (COVID-19) and Mental Health for Children and Adolescents. JAMA Pediatr. 2020, 174, 819. [CrossRef]

39. Orgilés, M.; Morales, A.; Delvecchio, E.; Mazzeschi, C.; Espada, J.P. Immediate psychological effects of the COVID-19 quarantine in youth from Italy and Spain. PsyArXiv 2020. Preprint. Available online: https://psyarxiv.com/5bpfz/ (accessed on 21 April 2020). [CrossRef]

40. Pisano, L.; Galimi, D.; Cerniglia, L. A qualitative report on exploratory data on the possible emotional/behavioral correlates of Covid-19 lockdown in 4-10 years children in Italy. PsyArXiv 2020. Preprint. Available online: https://psyarxiv.com/stwbn (accessed on 13 April 2020).

41. Song, S.Y.; Wang, C.; Espelage, D.L.; Fenning, P.; Jimerson, S.R. COVID-19 and School Psychology: Adaptations and New Directions for the Field. Sch. Psychol. Rev. 2020, 49, 431-437. [CrossRef]

42. Saurabh, K.; Ranjan, S. Compliance and Psychological Impact of Quarantine in Children and Adolescents due to Covid-19 Pandemic. Indian J. Pediatr. 2020, 87, 532-536. [CrossRef] [PubMed]

43. Pettoello-Mantovani, M.; Pop, T.L.; Mestrovic, J.; Ferrara, P.; Giardino, I.; Carrasco-Sanz, A.; Nigri, L.; Namazova-Baranova, L.; Vural, M.; Çokuğraş, F. Çullu Fostering Resilience in Children: The Essential Role of Healthcare Professionals and Families. J. Pediatr. 2019, 205, 298-299. [CrossRef] [PubMed]

44. Schaffer, G.E.; Power, E.M.; Fisk, A.K.; Trolian, T.L. Beyond the four walls: The evolution of school psychological services during the COVID-19 outbreak. Psychol. Sch. 2021, 58, 1246-1265. [CrossRef]

45. Stapley, T.A. Grounded Theory Study on the Development of a Professional Identity in Trainee Counselling Psychologists. Ph.D. Thesis, London Metropolitan University, London, UK, 2014. 
46. Ramalingam, P.; Nath, Y. School psychology in India: A vision for the future. J. Indian Acad. Appl. Psychol. 2012, 38, 22-33. Available online: https://www.researchgate.net/profile/Panch-Ramalingam/publication/287462594_School_psychology_in_India_ A_vision_for_the_future/links/5f42974b92851cd302203a73/School-psychology-in-India-A-vision-for-the-future.pdf (accessed on 12 August 2021).

47. Tangdhanakanond, K.; Lee, D.H. Thai and Korean Students' perceptions about the roles and functions of school psychologists. Sch. Psychol. Int. 2013, 35, 115-121. [CrossRef]

48. Eurydice. Greece overview: Main points of the educational system. 2021. Available online: https://eacea.ec.europa.eu/nationalpolicies/eurydice (accessed on 12 August 2021).

49. Hellenic Statistical Authority. Calculated Population and Migration Flows of the Country of 2016. Available online: www. statistics.gr (accessed on 29 December 2017).

50. Institute of Educational Policy. Student dropout in Greek primary and secondary education: Reference period: 2014-2017, 2019, Athens. Available online: http:/ / www.iep.edu.gr/images/IEP/EPISTIMONIKI_YPIRESIA/Epist_Grafeia/Diereynisisapotimisis/2019/2019-03-28_ekthesi_diarrois_2014-2017.pdf (accessed on 28 March 2019).

51. Hatzichristou, C.; Polychroni, F. The Preparation of School Psychologists in Greece. Int. J. Sch. Educ. Psychol. 2014, 2, 154-165. [CrossRef]

52. Castillo, J.M.; Curtis, M.J.; Tan, S.Y. Personnel needs in school psychology: A 10-year follow-up study on predicted personnel shortages. Psychol. Sch. 2014, 51, 832-849. [CrossRef]

53. Castillo, J.M.; Wolgemuth, J.R.; Barclay, C.; Mattison, A.; Tan, S.Y.; Sabnis, S.; Brundage, A.; Marshall, L. A qualitative study of facilitators and barriers related to comprehensive and integrated school psychological services. Psychol. Sch. 2016, 53, 641-658. [CrossRef]

54. Armistead, R.J.; Smallwood, D.L. The National Association of School Psychologists Model for Comprehensive and Integrated School Psychological Services. In Best Practices I School Psychology: Data-Based and Collaborative Decision Making; Harrison, P.L., Thomas, A., Eds.; National Association of School Psychologists: Bethesda, MD, USA, 2014; pp. 9-24.

55. Wright, A.J.; Mihura, J.L.; Pade, H.; Mccord, D.M. Guidance on Psychological Tele-Assessment during the COVID-19 Crisis; American Psychological Association (APA): Washington, DC, USA, 2020. Available online: https://www.apaservices.org/practice/ reimbursement/health-codes/testing/tele-assessment-covid-19 (accessed on 3 April 2020).

56. Stoiber, K.C.; Vanderwood, M.L. Traditional Assessment, Consultation, and Intervention Practices: Urban School Psychologists' Use, Importance, and Competence Ratings. J. Educ. Psychol. Consult. 2008, 18, 264-292. [CrossRef]

57. Moolla, N.; Lazarus, S. School psychologists' view on challenges in facilitating school development through inter-sectoral collaboration. S. Afr. J. Educ. 2014, 34, 1-10. [CrossRef]

58. McKenzie, K.; Murray, G.C.; Prior, S.; Stark, L. An evaluation of a school counselling service with direct links to Child and Adolescent Mental Health (CAMH) services. Br. J. Guid. Couns. 2011, 39, 67-82. [CrossRef]

59. Georgiadou, E.; Berki, E.; Valtanen, J.; Siakas, K.V.; Rahanu, H.; Edwards, J.A.; Paltalidis, N.; Agouropoulos, A.; Hatzipanagos, S.; McGuinness, C.; et al. Challenges of rapid migration to fully virtual education in the age of the Corona virus pandemic: Experiences from across the world. In Proceedings of the Twenty Fifth International e-Conference on Software Process Improvement Research, Education and Training, (INSPIRE XXV); Uhomoibhi, J., Dewar, E., Georgiadou, E., Linecar, P., Marchbank, P., Ross, M., Staples, G., Eds.; Solent University: Southampton, UK, 2020; ISBN 9781999654948.

60. Panteri, M.; Zirki, A.; Lambrou, G.; Valtanen, J.; Berki, E.; Lampropoulos, G.; Soylu, D.; Siakas, K.; Georgiadou, E.; Edwards, A.; et al. The Impact of the COVID-19 Pandemic on the Learning and Wellbeing of Secondary School Students: A Survey in Southern Europe. In Proceedings of the Twenty Sixth International e-Conference on Software Process Improvement Research, Education and Training (INSPIRE XXVI); Solent University: Southampton, UK, 2021; ISBN 97819996549. 